\title{
Extranodal marginal zone lymphoma of the dura mater with IgH/MALT1 translocation and review of literature
}

\author{
Sharathkumar Bhagavathi • Timothy C. Greiner • \\ Syed A. Kazmi • Kai Fu • Warren G. Sanger • \\ Wing C. Chan
}

Received: 14 December 2007 / Accepted: 9 April 2008/Published online: 18 June 2008

(C) Springer-Verlag 2008

\begin{abstract}
Primary central nervous system lymphoma (PCNSL) is an extranodal non-Hodgkin lymphoma involving brain, intraocular structures and spinal cord, without evidence of systemic disease. The majority of PCNSLs are diffuse large B-cell type. We encountered a rare case of primary dural marginal zone lymphoma of mucosa-associated lymphoid tissue (MALT) with extension into the brain in a 59-year-old man. A magnetic resonance imaging scan showed a 22-mm tumor located in the left posterior temporal lobe extending from the dura. Histopathology revealed a lymphoplasmacytic infiltration of the dura and the brain parenchyma in a perivascular pattern. Immunohistochemical and in situ hybridization studies showed a B-cell phenotype with kappa light chain restriction. Fluorescent in situ hybridization study showed a $t(14 ; 18)(q 32$; q21) with immunoglobulin heavy-chain/MALT1 fusion. The
\end{abstract}

\author{
S. Bhagavathi \\ Department of Anatomic Pathology, \\ William Beaumont Hospital, Royal Oak, MI 48076, USA \\ T. C. Greiner · S. A. Kazmi $\cdot$ K. Fu • W. C. Chan \\ Department of Pathology and Microbiology, \\ University of Nebraska Medical Center, \\ 983135, Nebraska Medical Center, \\ Omaha, NE 68198-3135, USA \\ W. G. Sanger \\ Department of Cytogenetic, \\ University of Nebraska Medical Center, \\ 983135, Nebraska Medical Center, \\ Omaha, NE 68198-3135, USA \\ W. C. Chan $(\bowtie)$ \\ Center for Lymphoma and Leukemia Research, \\ University of Nebraska Medical Center, \\ 983135, Nebraska Medical Center, \\ Omaha, NE 68198-3135, USA \\ e-mail: jchan@unmc.edu
}

molecular study for immunoglobulin heavy-chain gene rearrangement by polymerase chain reaction showed a clonal gene rearrangement.

Keywords Primary CNS · MALT lymphoma · FISH · $\mathrm{t}(1418) \cdot$ MALT1 translocation $\cdot$ Dura

\section{Introduction}

The majority of the central nervous system (CNS) lymphomas are due to the spread of a systemic lymphoma to the CNS $[1,2]$. Primary central nervous system lymphoma (PCNSL) is an extranodal non-Hodgkin lymphoma (NHL) that involves the brain, leptomeninges, intraocular structures, or spinal cord in the absence of systemic disease. It occurs in both immunocompromised and immunocompetent patients and accounts for $2.7 \%$ of all malignant diseases of the central nervous system [3]. The incidence of PCNSL has increased during the last three decades, and it occurs at a younger age in the immunocompromised patients.

According to World Health Organization classification [4], the majority of PCNSL are diffuse large B-cell lymphoma. T-cell (T-PCNSL), low grade B-cell lymphomas, and anaplastic large cell lymphoma of the CNS are extremely rare $[5,6]$. The PCNSL in human immunodeficiency virus positive patients is almost always associated with the Epstein-Barr virus (EBV), while the association of EBV in immunocompetent patients is rare [7].

The majority of PCNSL presents as a space-occupying lesion within the brain parenchyma and periventricular regions. Primary dural CNS lymphomas are extremely rare. The majority of them are low grade NHL, with marginal zone B-cell lymphoma being the most common. There are 
only a handful of case reports and a small case series which describe the dural involvement [8-10]. In the present study, we describe the clinical, histopathological, immunohistochemical, cytogenetic, and molecular findings of a case of primary extranodal marginal zone lymphoma involving the dura with extension to the brain parenchyma in an immunocompetent patient. This is the first report of a primary dural marginal zone lymphoma of mucosa-associated lymphoid tissue (MALT) type that has shown a molecular rearrangement of $\mathrm{t}(14 ; 18)(\mathrm{q} 32 ; \mathrm{q} 21)$ involving the MALT1gene.

\section{Material and methods}

All available routine hematoxylin and eosin, immunohistochemical, and in situ hybridization slides of formalin-fixed paraffin-embedded tissue from a diagnostic biopsy of the patient were reviewed. Working antibody source, clone, and dilution are listed in Table 1. Staining was performed on an automated immunostainer (Ventana Medical Systems, Tuscon, AZ and Dako, Carpentaria, CA, USA). For in situ hybridization (ISH), slides were deparaffinized and antigen retrieval was performed by a Ventana's proprietary protease-1 treatment. Subsequently, the slides were incubated with undiluted Kappa, Lambda, and EBV probe solutions from Ventana.

\section{Fluorescent in situ hybridization}

Fluorescence in situ hybridization (FISH) was performed on $4-5-\mu \mathrm{m}$ unstained paraffin-embedded tissue sections using the LSI immunoglobulin heavy-chain (IgH)/MALT1 dual-fusion translocation probe and the LSI BCL6 (3q27) dual-color break-apart probe obtained from Vysis/Abbott, Inc. (Downer's Grove, IL, USA). Prior to hybridization, the slides were pretreated by utilizing the VP 2000 automated slide processor (Vysis/Abbott, Inc.) following a modified version of the manufacturer's recommended protocol.

Table 1 Panel of antibodies

\begin{tabular}{llll}
\hline Antibody to & Clone & Company & Dilution \\
\hline CD20 & L26 & Dako $^{\mathrm{a}}$ & $1: 500$ \\
CD79a & JCB117 & Dako & $1: 80$ \\
CD3 & F7.2.38 & Dako & Neat \\
CD5 & SP19 & Ventana $^{\mathrm{b}}$ & Neat \\
Cyclin D1 & SP4 & Ventana & $1: 100$ \\
CD21 & 1F8 & Dako & $1: 80$ \\
Ig G & A57H & Dako & $1: 200$ \\
Ig M & R1/69 & Dako & $1: 200$ \\
CD10 & 56C6 & Ventana & Neat
\end{tabular}

${ }^{a}$ Dako, Carpenteria, CA, USA

${ }^{\mathrm{b}}$ Ventana, Tucson, AZ, USA
Codenaturation of the DNA probe and the tissue DNA was performed on a HYBrite ${ }^{\mathrm{TM}}$ instrument (Vysis/Abbott, Inc., IL, USA) at $80^{\circ} \mathrm{C}$ for $5 \mathrm{~min}$, followed by an overnight hybridization at $37^{\circ} \mathrm{C}$, postwashed in $2 \times \mathrm{SSC} /$ $0.3 \% \mathrm{NP}-40$ at $73^{\circ} \mathrm{C}$ for $2 \mathrm{~min}$, and counterstained with 4',6-diamidino-2-phenylindole II.

\section{Molecular diagnostics}

Immunoglobulin heavy-chain gene rearrangements were analyzed by using the InVivoScribe IgH framework III/ heavy-chain joining $(\mathrm{JH})$ assay, according to the manufacturer's protocol (InVivoScribe Technologies, San Diego, CA, USA). Framework II/JH segments were amplified using the forward (5' TGG RTC CGM CAG SCY YCN GG $\left.3^{\prime}\right)$ and reverse (5' 6-FAM ACC TGA GGA GAC GGT GAC C $3^{\prime}$ ) primers as previously described [11]. Polymerase chain reaction (PCR) products were analyzed using a capillary electrophoresis as described previously [12].

\section{Case report}

The patient was a 59-year-old gentleman, who presented with speech difficulties, right-sided numbness, and episodes of unusual smell for 8 months. He did not have a history of headache, seizures, and inflammatory conditions. A magnetic resonance imaging scan showed a heterogeneously enhancing 22-mm tumor located in the left posterior temporal lobe abutting the dura. Subsequently, he underwent left temporal craniotomy and microsurgical resection of the tumor. The patient underwent computed tomography scans of the chest, abdomen, and pelvis (staging), with normal findings. Bone marrow aspiration and biopsy examinations did not reveal any evidence of lymphoma. A work-up for monoclonal gammopathy including serum protein electrophoresis and serum level of immunoglobulin A, $\mathrm{G}$, and $\mathrm{M}$ showed normal results.

\section{Results}

The histopathology of the tumor showed a prominent lymphoplasmacytic infiltration in the brain parenchyma and the overlying fibrous (dura) tissue. The tumor showed a characteristic, angiocentric pattern, forming cuffs of tumor cells around the cerebral blood vessels (Virchow-Robin space; Fig. 1A,B). Most of the lymphocytes were small with condensed chromatin in a round to slightly irregular nucleus and a scant to moderate amount of pale cytoplasm. A prominent plasma cell population was present. Reactive lymphoid follicles were not identified.

Immunohistochemical studies showed that the tumor cells were positive for B-cells markers (cluster of differen- 
Fig. 1 Morphologic, immunohistochemical, Ig light chain expression and FISH assay of the PCNS MALT lymphoma. A and B Histopathology of the lymphoma showing a prominent lymphoplasmacytic infiltration with a characteristic perivascular pattern (hematoxylin-eosin, original magnification, $\times 100$ and $\times 400$ ). C and D Many of the lymphoma cells were positive for CD 20 and CD 79a (immunohistochemistry $\times 100$ ). E In situ hybridization showing the tumor cells are kappa light chain restricted $(\times 100)$. F In situ hybridization showing the tumor cells are lambda light chain negative $(\times 100)$. G FISH analysis showing the interphase cells with IGH/MALT1 rearrangement indicated by two fusion signals (juxtaposed green and red signal). The normal IgH and MALT1 loci are represented by the single red and single green signals respectively $(\times 100)$

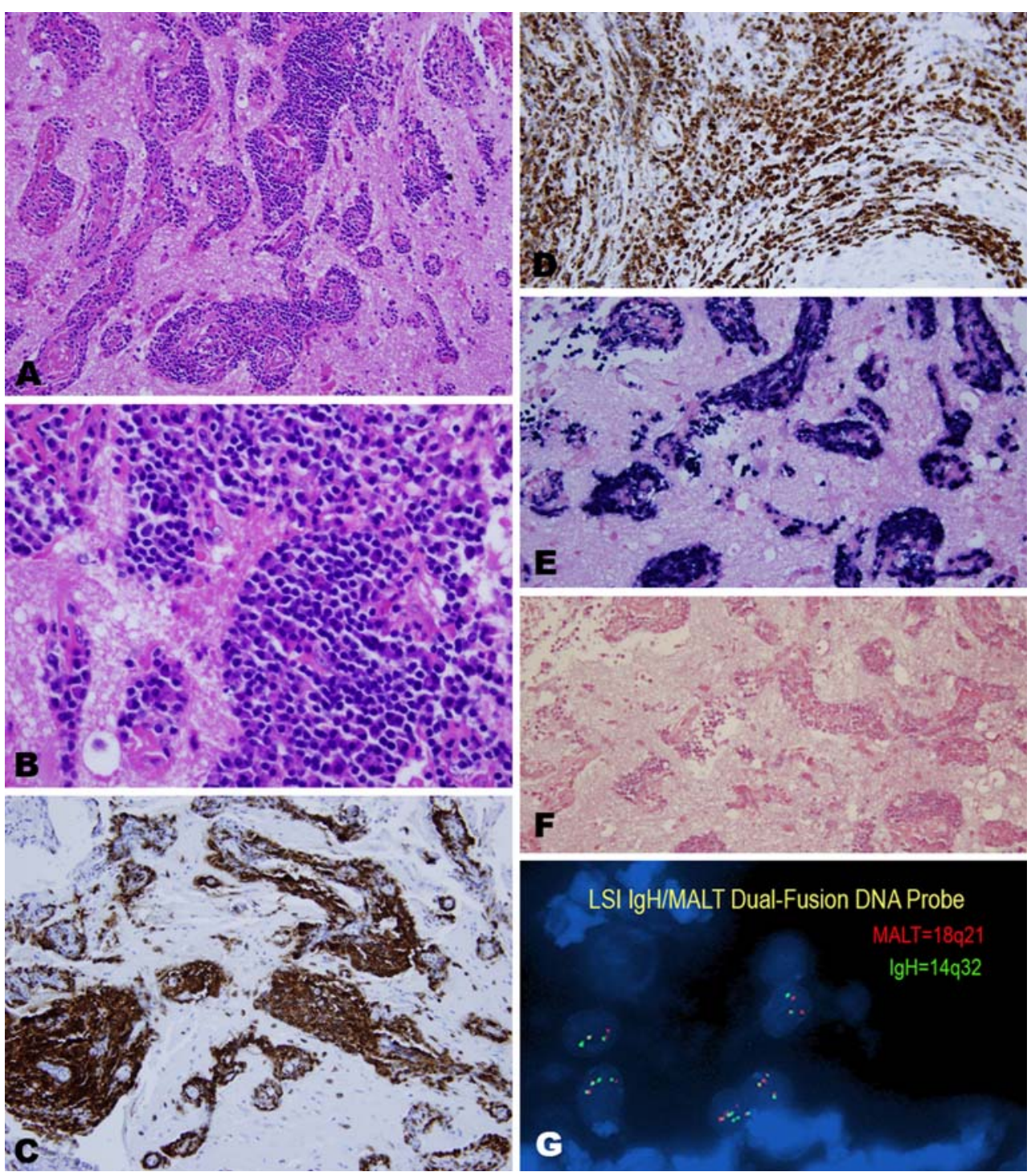

tiation (CD) 20, CD79a; Fig. 1C,D). The neoplastic plasma cells were monoclonal for Ig $G$ and kappa light chain (Fig. 1E), and negative for lambda light chain (Fig. 1F). The tumor cells were immunonegative for CD3, CD5, cyclin D1, CD21, CD23, CD10, and Ig M. EBV testing by ISH (EBV-encoded small RNA) was negative. The FISH study for MALT1 translocations showed a rearrangement of the MALT1 region at 18q21 in 30\% of the interphase cells. Subsequent studies showed fusion of IgH/MALT1 in $74 \%$ of the cells (Fig. 1G). Additional studies for trisomy 3 and 7 were negative. The molecular study for IgH rearrangement by PCR showed a single peak indicating clonal immunoglobulin heavy-chain gene rearrangement using the primers for heavy-chain variable (VH; framework II) and $\mathrm{JH}$ regions (Fig. 2). The tumor was negative for clonal $\mathrm{IgH}$ gene by PCR using the primers to VH framework III and $\mathrm{JH}$ regions. The staging evaluation was negative for systemic involvement by lymphoma.

\section{Discussion}

Isaacson and Wright were the first to describe the marginal zone B-cell lymphoma (MZL) in mucosa-associated lymphoid tissue of the gastrointestinal tract in 1983 [13]. Depending on the site of involvement, the MZL is classified into three subtypes: (1) splenic MZL, (2) nodal MZL, and (3) extranodal MZL of the mucosa-associated lymphoid tissues type $[14,15]$.

Among the MALT lymphomas, the gastrointestinal tract and lungs are the most common sites [16]. It is also recognized in salivary glands, skin, thyroid, lung, ocular adnexa, liver, CNS, and breast [17]. MALT lymphoma of the CNS is extremely rare. Dural MALT lymphoma is the most common site of involvement in the CNS with a rare occurrence in the lateral ventricle $[18,19]$.

To date, 39 cases of primary dural MALT lymphomas have been reported in the literature (Table 2). They usually 


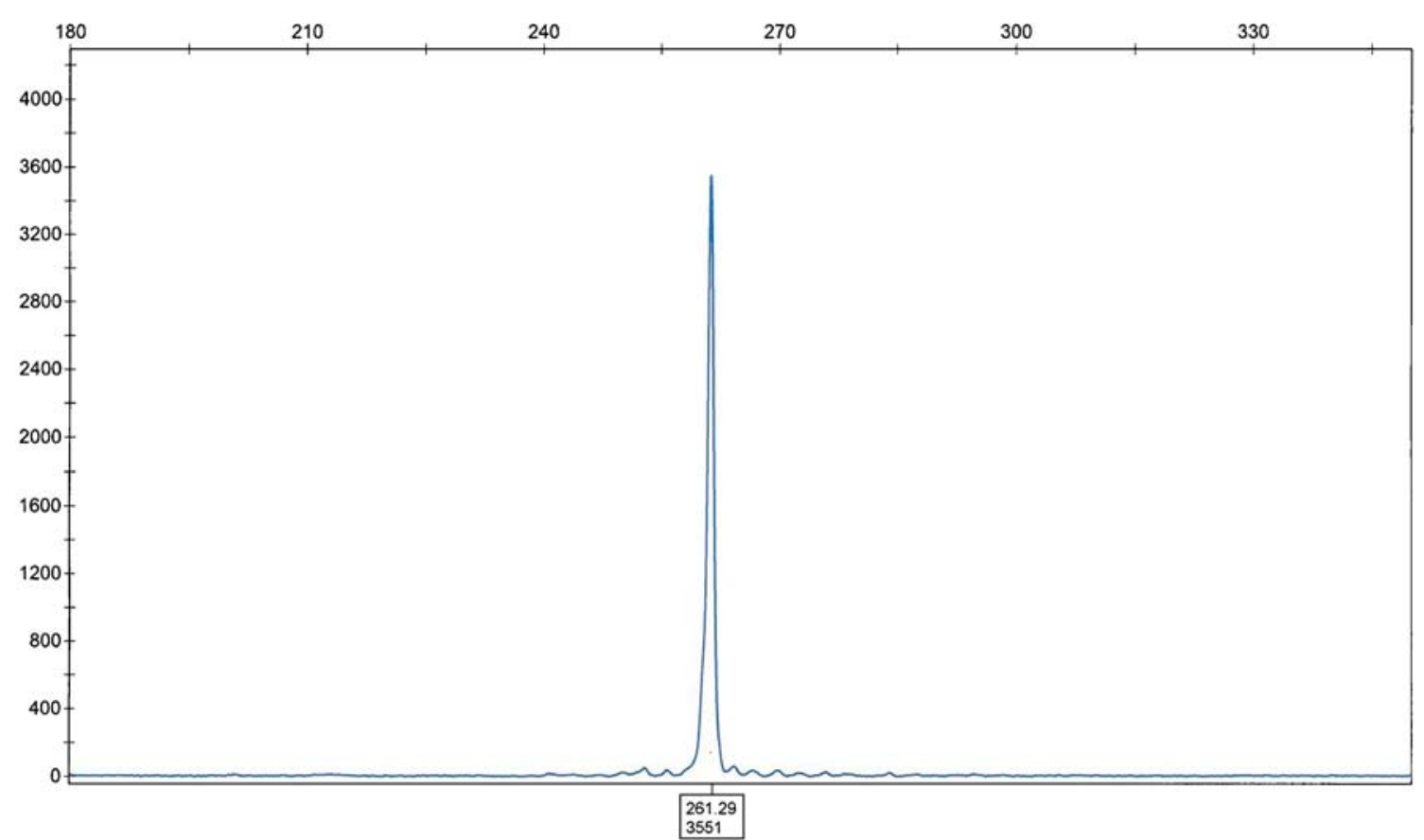

Fig. 2 Immunoglobulin heavy-chain gene rearrangement study-PCR product analyzed by capillary electrophoresis showing a clonal rearrangement. $X$ axis length of amplicon, $Y$ axis intensity of signal

occur in the middle-aged to elderly women and present with headache, seizures, and visual disturbance [18]. Although CNS is devoid of mucosal tissue, it has been hypothesized that the meningothelial cells serve as a substitute for the mucosal surface in MALT lymphoma of the CNS [20, 21].

MALT lymphomas typically present as a local mass without bone marrow and lymph node involvement in

Table 2 Clinicopathological features of the reported cases of primary central nervous system lymphoma of mucosa-associated lymphoid tissue type

\begin{tabular}{|c|c|c|c|c|c|c|c|c|c|c|c|}
\hline Case & Reference & Location of dura & $\begin{array}{l}\text { Presenting } \\
\text { symptoms }\end{array}$ & $\begin{array}{l}\text { Age } \\
\text { (years) }\end{array}$ & Sex & $\begin{array}{l}\text { Preexisting } \\
\text { condition }\end{array}$ & Treatment & $\begin{array}{l}\text { FISH } \\
\text { studies }\end{array}$ & $\begin{array}{l}\operatorname{IgH} \\
\text { studies }\end{array}$ & $\begin{array}{l}\text { Follow up } \\
\text { (months) }\end{array}$ & Status \\
\hline 1 & $\begin{array}{l}\text { Kumar et al. } \\
\text { [21] }\end{array}$ & Cavernous sinus & $\begin{array}{l}\text { Numbness and } \\
\text { visual field defects }\end{array}$ & 40 & $\mathrm{~F}$ & None & RT & ND & ND & 63 & CR1 \\
\hline 2 & $\begin{array}{l}\text { Kumar et al. } \\
\text { [21] }\end{array}$ & Biparietal & Seizures & 62 & $\mathrm{~F}$ & None & Chemo & ND & Mono & 22 & CR1 \\
\hline 3 & $\begin{array}{l}\text { Kumar et al. } \\
\text { [21] }\end{array}$ & Frontal & Seizures; numbness & 52 & $\mathrm{~F}$ & None & $\begin{array}{l}\mathrm{RT} \text { and } \\
\text { chemo }\end{array}$ & ND & Mono & 7 & CR1 \\
\hline 4 & $\begin{array}{l}\text { Kumar et al. } \\
\text { [21] }\end{array}$ & Tentorium & $\begin{array}{l}\text { Headache, visual } \\
\text { defect, numbness }\end{array}$ & 43 & $\mathrm{~F}$ & None & RT & ND & Negative & 9 & CR1 \\
\hline 5 & $\begin{array}{l}\text { Kumar et a1. } \\
\text { [21] }\end{array}$ & Falx cerebri & Seizures & 57 & $\mathrm{~F}$ & None & RT & ND & Mono & 14 & CR1 \\
\hline 6 & $\begin{array}{l}\text { Kambham et al. } \\
{[26]}\end{array}$ & Tentorium & $\begin{array}{l}\text { Hearing loss, } \\
\text { weakness }\end{array}$ & 39 & $\mathrm{~F}$ & None & Resection & ND & Mono & 48 & AWD \\
\hline 7 & $\begin{array}{l}\text { Kambham et al. } \\
\text { [26] }\end{array}$ & Frontoparietal & $\begin{array}{l}\text { Headache, visual } \\
\text { defect, numbness }\end{array}$ & 62 & $\mathrm{~F}$ & None & $\begin{array}{c}\text { Resection } \\
\text { and RT }\end{array}$ & ND & Negative & 6 & AWD \\
\hline 8 & $\begin{array}{l}\text { Altundag et al. } \\
\text { [27] }\end{array}$ & Parietal & Seizures & 66 & $\mathrm{~F}$ & None & Resection & ND & ND & 12 & CR1 \\
\hline 9 & $\begin{array}{l}\text { Itoh et al. } \\
{[20]}\end{array}$ & Cerebellopontine & Tinnitus, headache & 28 & $\mathrm{~F}$ & $\begin{array}{l}\text { Sjogren's } \\
\text { syndrome }\end{array}$ & Resection & ND & ND & 24 & CR1 \\
\hline 10 & $\begin{array}{l}\text { Sanjeevi et al. } \\
\text { [28] }\end{array}$ & Cavernous sinus & $\begin{array}{l}\text { Headache, visual } \\
\text { defect }\end{array}$ & 46 & $\mathrm{~F}$ & $\begin{array}{l}\text { Grave's } \\
\text { disease }\end{array}$ & $\begin{array}{c}\text { Resection } \\
\text { and RT }\end{array}$ & ND & ND & 15 & CR1 \\
\hline 11 & $\begin{array}{l}\text { Goetz et al. } \\
\text { [29] }\end{array}$ & Frontoparietal & Hemiparesis & 64 & $\mathrm{~F}$ & None & $\begin{array}{l}\text { Resection } \\
\text { and RT }\end{array}$ & ND & ND & 3 & CR1 \\
\hline 12 & Bodi et al. [30] & Frontal & Seizures, dizziness & 56 & $\mathrm{~F}$ & None & Resection & ND & ND & 18 & CR1 \\
\hline 13 & $\begin{array}{l}\text { Lehman et al. } \\
\text { [31] }\end{array}$ & Falx cerebri & $\begin{array}{l}\text { Seizures, speech } \\
\text { defect }\end{array}$ & 63 & $\mathrm{~F}$ & None & RT & ND & ND & 8 & AWD \\
\hline
\end{tabular}


Table 2 (continued)

\begin{tabular}{|c|c|c|c|c|c|c|c|c|c|c|c|}
\hline Case & Reference & Location of dura & $\begin{array}{l}\text { Presenting } \\
\text { symptoms }\end{array}$ & $\begin{array}{l}\text { Age } \\
\text { (years) }\end{array}$ & Sex & $\begin{array}{l}\text { Preexisting } \\
\text { condition }\end{array}$ & Treatment & $\begin{array}{l}\text { FISH } \\
\text { studies }\end{array}$ & $\begin{array}{l}\mathrm{IgH} \\
\text { studies }\end{array}$ & $\begin{array}{l}\text { Follow up } \\
\text { (months) }\end{array}$ & Status \\
\hline 14 & $\begin{array}{l}\text { Benouaich et al. } \\
\text { [32] }\end{array}$ & Frontoparietal & Headache & 38 & $\mathrm{~F}$ & None & $\begin{array}{l}\mathrm{RT} \text { and } \\
\text { chemo }\end{array}$ & ND & ND & 24 & CR1 \\
\hline 15 & $\begin{array}{l}\text { Benouaich et al. } \\
\text { [32] }\end{array}$ & $\begin{array}{l}\text { Temporal, } \\
\text { parieto-occipital }\end{array}$ & Headache & 45 & $\mathrm{~F}$ & None & $\begin{array}{l}\text { RT and } \\
\text { chemo }\end{array}$ & ND & ND & 12 & CR1 \\
\hline 16 & $\begin{array}{l}\text { Kelly et al. } \\
{[18]}\end{array}$ & Choroid plexus & Headache, seizures & 53 & M & None & $\begin{array}{c}\text { Resection } \\
\text { and RT }\end{array}$ & Negative & ND & 12 & CR1 \\
\hline 17 & Tu et al. [25] & Falx cerebri & NA & 56 & $\mathrm{~F}$ & None & $\begin{array}{l}\text { Not } \\
\text { available }\end{array}$ & Tri 3 & Negative & NA & NA \\
\hline 18 & Tu et al. [25] & Frontal dura & Seizures & 49 & M & None & Chemo & Tri 3 & Negative & 90 & CR1 \\
\hline 19 & Tu et al. [25] & Frontal dura & Seizures & 66 & M & None & RT & Tri 3 & Negative & 13 & CR1 \\
\hline 20 & Tu et al. [25] & Posterior fossa & NA & 55 & $\mathrm{~F}$ & None & NA & ND & Negative & NA & NA \\
\hline 21 & Tu et al. [25] & $\begin{array}{l}\text { Middle cranial } \\
\text { fossa }\end{array}$ & NA & 45 & $\mathrm{~F}$ & None & NA & ND & Negative & NA & NA \\
\hline 22 & Tu et al [25] & NA & NA & 68 & $\mathrm{~F}$ & None & NA & Tri 3 & Negative & NA & NA \\
\hline 23 & Tu et al. [25] & Subdural & NA & 29 & $\mathrm{~F}$ & None & RT & Negative & Negative & 36 & CR1 \\
\hline 24 & Tu et al. [25] & Frontotemporal & $\begin{array}{l}\text { Headache, } \\
\text { drowsiness }\end{array}$ & 61 & $\mathrm{~F}$ & None & NA & Negative & Negative & 21 & CR1 \\
\hline 25 & Tu et al. [25] & Occipital & Ataxia & 62 & $\mathrm{~F}$ & None & RT & $\begin{array}{l}\text { Tri } 3,7 \\
12,18\end{array}$ & Negative & 25 & CR1 \\
\hline 26 & Tu et al. [25] & Parietal & $\begin{array}{c}\text { Facial drop, } \\
\text { numbness, } \\
\text { dysarthria }\end{array}$ & 47 & M & None & NA & ND & ND & NA & NA \\
\hline 27 & Tu et al. [25] & Frontoparietal & Right arm pain & 57 & $\mathrm{~F}$ & None & $\begin{array}{l}\mathrm{RT} \text { and } \\
\text { chemo }\end{array}$ & Negative & Negative & 65 & CR1 \\
\hline 28 & Tu et al. [25] & Tentorium & Visual deficits & 70 & $\mathrm{~F}$ & None & RT & Negative & Negative & 45 & CR1 \\
\hline 29 & Tu et al. [25] & Falx & $\begin{array}{l}\text { Gait disturbance, } \\
\text { visual deficits }\end{array}$ & 59 & $\mathrm{~F}$ & None & RT & Negative & Negative & 32 & CR1 \\
\hline 30 & Tu et al. [25] & Suprasellar, sella & $\begin{array}{l}\text { Headache, visual } \\
\text { deficits }\end{array}$ & 53 & $\mathrm{~F}$ & None & RT & Negative & Negative & 11 & CR1 \\
\hline 31 & Tu et al. [25] & Falx tentorium & Headache, ear pain & 48 & $\mathrm{~F}$ & None & $\begin{array}{l}\text { RT and } \\
\text { chemo }\end{array}$ & $\begin{array}{c}\text { Tri } 3,7, \\
12,18\end{array}$ & Negative & 20 & CR1 \\
\hline 32 & $\begin{array}{l}\text { Iwamoto et al. } \\
\text { [33] }\end{array}$ & Temporoparietal & $\begin{array}{l}\text { Headache, facial } \\
\text { weakness }\end{array}$ & 64 & $\mathrm{~F}$ & None & $\begin{array}{l}\text { Resection } \\
\text { and } \\
\text { chemo }\end{array}$ & ND & ND & 78 & CR1 \\
\hline 33 & $\begin{array}{l}\text { Iwamoto et al. } \\
\text { [33] }\end{array}$ & Frontotemporal & $\begin{array}{l}\text { Seizures, visual } \\
\text { defects }\end{array}$ & 33 & $\mathrm{~F}$ & None & $\begin{array}{r}\mathrm{RT} \text { and } \\
\text { chemo }\end{array}$ & ND & ND & 84 & CR1 \\
\hline 34 & $\begin{array}{l}\text { Iwamoto et al. } \\
\text { [33] }\end{array}$ & $\begin{array}{c}\text { Tentorium, } \\
\text { temporal }\end{array}$ & $\begin{array}{c}\text { Headache, } \\
\text { dizziness, } \\
\text { numbness }\end{array}$ & 35 & $\mathrm{M}$ & None & $\begin{array}{l}\text { RT and } \\
\text { chemo }\end{array}$ & ND & ND & 53 & CR1 \\
\hline 35 & $\begin{array}{l}\text { Iwamoto et al. } \\
\text { [33] }\end{array}$ & Tentorium & Seizures & 47 & M & None & RT & ND & ND & 27 & CR1 \\
\hline 36 & $\begin{array}{l}\text { Iwamoto et al. } \\
\text { [33] }\end{array}$ & Frontal, sphenoidal & $\begin{array}{l}\text { Visual deficits, } \\
\text { paresthesias }\end{array}$ & 39 & $\mathrm{~F}$ & None & RT & ND & ND & 6 & CR1 \\
\hline 37 & $\begin{array}{l}\text { Iwamoto et al. } \\
\text { [33] }\end{array}$ & Parietal & Seizures & 49 & $\mathrm{~F}$ & None & RT & ND & ND & 7 & CR1 \\
\hline 38 & $\begin{array}{l}\text { Iwamoto et al. } \\
\text { [33] }\end{array}$ & Frontal & Headache & 51 & $\mathrm{~F}$ & None & RT & ND & ND & 8 & CR1 \\
\hline 39 & $\begin{array}{l}\text { Iwamoto et al. } \\
\text { [33] }\end{array}$ & Frontal & $\begin{array}{l}\text { Headache, visual } \\
\text { deficits }\end{array}$ & 50 & $\mathrm{~F}$ & None & RT & ND & ND & 5 & CR1 \\
\hline 40 & $\begin{array}{l}\text { Bhagavathi et al. } \\
\text { [present report] }\end{array}$ & Temporal & $\begin{array}{l}\text { Altered speech, } \\
\text { numbness }\end{array}$ & 59 & $\mathrm{M}$ & None & RT & $\begin{array}{l}\mathrm{t}(14 ; 18) \\
(\mathrm{q} 32 ; \\
\mathrm{q} 21)\end{array}$ & Mono & 1 & AWD \\
\hline
\end{tabular}

$M$ Male, $F$ female $R T$ radiotherapy, chemo chemotherapy, $N D$ not done, $C R$ complete remission, $A W D$ alive with disease, $N A$ not available, $F I S H$ fluorescent in situ hybridization, IgH immunoglobulin heavy-chain gene rearrangement, mono monoclonal 
contrast to nodal and splenic MZL. They arise from the marginal zone B-cells and show a spectrum of cellular constituents, from small lymphocytes to monocytoid B-cells to plasma cells. The lymphocytes express B-cell markers (CD19, CD20, and CD79a) and are negative for CD3, CD5, CD10, CD23, and cyclin D1.

In the present case, the morphological, immunohistochemical, and in situ hybridization studies showed that the lymphoma is a low grade MZL, with prominent plasma cell differentiation that is Ig G and kappa light chain restricted. The tumor infiltrated into the underlying brain parenchyma in a perivascular pattern. Small lymphocytic lymphoma/ chronic lymphocytic leukemia and mantle-cell lymphomas were excluded by the negative immunostaining for $\mathrm{CD} 5$, CD23, and cyclin D1. Follicular lymphoma and lymphoplasmacytic lymphoma were excluded by the morphology, negative CD10, normal serum Ig $\mathrm{M}$, and negative bone marrow examination.

Infectious or inflammatory conditions were ruled out by the demonstration of a dominant clonal population. In situ hybridization showed that the plasma cells are Kappa light chain restricted, while molecular study for $\operatorname{IgH}$ gene rearrangement showed a clonal immunoglobulin heavychain gene rearrangement.

MALT lymphoma, notably in the lung and gastrointestinal tract, often has a characteristic $\mathrm{t}(11 ; 18)(\mathrm{q} 21 ; \mathrm{q} 21)$ translocation. In this translocation, the $3^{\prime}$ end of MALT1 was fused to the $5^{\prime}$ portion of API2, an inhibitor of apoptosis located at 11q21 leading to production of API2MALT1 fusion transcript [22]. The frequency of this translocation varies depending on the site of origin of the tumor and it was absent or present at very low frequencies in thyroid, skin, liver, and other rare sites [23].

Streubel et al. [24] have identified a second chromosomal aberration involving the MALT1 gene and $\operatorname{IgH}$ on $14 \mathrm{q} 32$ rather than the API2. Their study showed that $18 \%$ (12 out of 66) of the MALT lymphomas were positive for $\mathrm{t}(14 ; 18)(\mathrm{q} 32 ; \mathrm{q} 21)$. Interestingly, the anatomical distribution of MALT lymphoma with $\mathrm{t}(14 ; 18)(\mathrm{q} 32 ; \mathrm{q} 21)$ was different from that with $\mathrm{t}(11 ; 18)(\mathrm{q} 21 ; \mathrm{q} 21)$. The $\mathrm{t}(14 ; 18)$ was positive in MALT lymphoma involving ocular adnexa, skin, and the salivary glands, and negative in pulmonary and gastrointestinal MALT lymphoma. MALT lymphomas with different chromosomal abnormalities involving different anatomical sites may indicate different pathogenetic pathways, e.g., the gastric MALT lymphoma is associated with $\mathrm{H}$ pylori, whereas those of ocular adnexa, skin, and salivary glands may be associated with other infectious agents or autoimmune diseases.

In the present case, FISH study showed a positive rearrangement of the MALT1 locus. Subsequent studies showed IgH/MALT1 fusion. To our knowledge, this is the first case of primary dural lymphoma of MALT type with a translocation involving IgH and MALT1 genes. The largest series of dural MALT lymphoma reported in the literature was by $\mathrm{Tu}$ et al. [25]. They were able to perform FISH study in 12 of the 15 cases. None of their cases showed $\mathrm{t}(14 ; 18)$ or $\mathrm{t}(11 ; 18)$ translocations. However, $50 \%$ of their cases showed trisomy 3 (six out of 12 cases) while our case was negative for this abnormality. Similarly, Kelly et al. [18] have also performed FISH study in their case report and the result was negative for $t(11 ; 18)$ and $t(14 ; 18)$. Additional cases of dural MALT lymphoma need to be studied by FISH to determine the precise frequency of MALT1 rearrangement. Our case suggests that MALT1 translocation play a pathogenetic role in some PCNS MALT lymphoma similar to the other extranodal lymphoma.

In conclusion, we report a rare case of primary dural MALT lymphoma with prominent plasmacytic differentiation and the diagnosis was confirmed by a monoclonal IgH gene rearrangement and a positive MALT1 rearrangement involving $\operatorname{IgH}$ and MALT1 on chromosome 14 and 18, respectively.

\section{References}

1. Law IP, Dick FR, Blom J et al (1975) Involvement of the central nervous system in non-Hodgkin's lymphoma. Cancer 36:225-231

2. Herman TS, Hammond N, Jones SE et al (1979) Involvement of the central nervous system by non-Hodgkin's lymphoma: the Southwest oncology group experience. Cancer 43:390-397

3. Central Brain Tumor Registry of the United States (2002-2003) Primary brain tumors in the United States 1995-1999: statistical report. CBTRUS, Chicago, IL

4. Kleihues P, Cavenee WK (2000) World Health Organization classification of tumors: pathology and genetics: tumors of the nervous system. IARC, Lyon

5. Abrey LE, Batchelor TT, Ferreri AJ et al (2005) Report of an international workshop standardize baseline evaluation and response criteria for primary CNS lymphoma. J Clin Oncol 23:5034-5043

6. Abrey LE, Ben-Porat L, Panageas KS et al (2006) Primary central nervous system lymphoma: the Memorial Sloan-Kettering Cancer Center prognostic model. J Cli Oncol 24:5711-5715

7. Camilleri-Broet S, Martin A, Moreau A et al (1998) Primary central nervous system lymphoma in 72 immunocompetent patients: pathologic findings and clinical correlations. Am J Clin Pathol 110:607-611

8. Hochberg FH, Miller DC (1988) Primary central nervous system lymphoma. J Neurosurg 68:835-853

9. Jazy FK, Shehata WM, Tew JM et al (1980) Primary intracranial lymphoma of the dura. Arch Neurol 37:528-529

10. Nguyen D, Nathwani BN (1989) Primary meningeal small lymphocytic lymphoma. Am J Surg Pathol 13:67-70

11. Theriault C, Galoin S, Valmary S, Selves J, Lamant L, Roda D et al (2000) PCR analysis of immunoglobulin heavy chain ( $\operatorname{IgH})$ and TCR- $\gamma$ chain gene rearrangements in the diagnosis of lymphoproliferative disorders: results of a study of 525 cases. Mod Path 13:1269-1279

12. Lawnicki LC, Rubocki RJ, Chan WC, Lytle DM, Greiner TC (2003) The distribution of gene segments in T-cell receptor 
gamma gene rearrangements demonstrates the need for multiple primer sets. J Mol Diagnostics 5:82-87

13. Isaacson P, Wright DH (1983) Malignant lymphoma of mucosaassociated lymphoid tissue: a distinctive type of B-cell lymphoma. Cancer 52:1410-1416

14. Harris NL, Jaffe ES, Stein H et al (1994) A revised EuropeanAmerican classification of lymphoid neoplasms. A proposal from the international lymphoma study group. Blood 84:1361-1392

15. Jaffe ES, Harris NL, Stein H et al (2001) World Health Organization classification of tumours: pathology and genetics of tumours of haematopoietic and lymphoid tissues. IARC, Lyon

16. Yuen A, Jacobs C (1999) Lymphomas of the head and neck. Semin Oncol 26:338-345

17. Zucca E, Conconi A, Pedrinis E et al (2003) International extranodal lymphoma study group: non gastric marginal zone B-cell lymphoma of mucosa-associated lymphoid tissue. Blood 101:2489-2495

18. Kelly TW, Prayson RA, Barnett GH et al (2005) Extranodal marginal zone B-cell lymphoma of mucosa-associated lymphoid tissue arising in the lateral ventricle. Leuk Lymphoma 46:1423-1427

19. Jung T, Jung S, Lee MC et al (2006) Extranodal marginal zone B-cell lymphoma mimicking meningioma in lateral ventricle: a case report and possible pathogenesis. J Neuro-oncol 80:63-67

20. Itoh T, Shimizu M, Kitami K et al (2001) Primary extranodal marginal zone B-cell lymphoma of the mucosa-associated lymphoid tissue type in the CNS. Neuropathology 21:174-180

21. Kumar S, Kumar D, Kaldjian EP et al (1997) Primary low-grade B-cell lymphoma of the dura: a mucosa associated lymphoid tissue-type lymphoma. Am J Surg Pathol 21:81-87

22. Uren AG, Pakusch M, Hawkins CJ et al (1996) Cloning and expression of apoptosis inhibitory protein homologs that function to inhibit apoptosis and/or bind tumor necrosis factor receptorassociated factors. Proc Nat Acad Sci U S A 93:4974-4978

23. Ye H, Liu H, Attygalle A et al (2003) Variable frequencies of $\mathrm{t}(11 ; 18)(\mathrm{q} 21 ; \mathrm{q} 21)$ in MALT lymphomas of different sites: significant association with CagA strains of $\mathrm{H}$. pylori in gastric MALT lymphoma. Blood 102:1012-1018

24. Streubel B, Lamprecht A, Dierlamn J et al (2003) T (14; 18) (q32; q21) and MALT1 is a frequent chromosomal aberration in MALT lymphoma. Blood 101:2335-2339

25. Tu PH, Giannini C, Judkins AR et al (2005) Clinicopathologic and genetic profile of intracranial marginal zone lymphoma: a primary low grade CNS lymphoma that mimics meningioma. J Clin Oncol 23:5718-5727

26. Kambham N, Chang Y, Matsushima AY (1998) Primary low grade B-cell lymphoma of mucosa associated lymphoid tissue (MALT) arising in dura. Clin Neuropathol 17:311-317

27. Altundag MK, Ozisik Y, Yalcin S et al (2000) Primary low grade B-cell lymphoma of the dura in an immunocompetent patient. J Exp Clin Cancer Res 19:249-251

28. Sanjeevi A, Krishnan J, Bailey PR et al (2001) Extranodal marginal zone B-cell lymphoma of malt type involving the cavernous sinus. Leuk Lymphoma 42:1133-1137

29. Goetz P, Lafuente J, Revesz T et al (2002) Primary low grade B-cell lymphoma of mucosa associated lymphoid tissue of the dura mimicking the presentation of an acute subdural hematoma. Case report and review of the literature. J Neurosurg 96:611-614

30. Bodi I, Hussain A, Gullan RW et al (2003) 56-years old female with right frontal tumor of the dura. Brain Pathol 13:417-423

31. Lehman NL, Horoupian DS, Warnke RA et al (2002) Dural marginal zone lymphoma with massive amyloid deposition: rare low grade primary central system B-cell lymphoma. Case report. J Neurosurg 96:368-372

32. Benouaich A, Delord JP, Danjou M et al (2003) Primary dural lymphoma: a report of two cases with review of the literature. Rev Neurol 159:652-658

33. Iwamoto FM, DeAngelis LM, Abrey LE (2006) Primary dural lymphoma: a clinicopathologic study of treatment and outcome in eight patients. Neurology 66:1763-1765 